lung transplantation is encouraging. This surgery offers a treatment for a wide range of end stage chronic lung disease.

We thank Mr Ben Milstein for editorial comments and criticisms; Ms Noreen Caine for the mortality statistics; Professor M Turner-Warwick, Dr J C Batten, Dr M E Hodson, Dr S W Clarke, Dr G M Jeremiah, Wing Commander W Hopkirk, and Dr M M Webb-Pearce for referring patients; the staff at the hospitals from which we obtained donor organs for their help; and Miss K Lightfoot for preparing the manuscript.

\section{References}

1 Reitz BA, Wallwork J, Hunt SA, et al. Heart-lung transplantation: a successful therapy for patients with pulmonary vascular disease. $N$ Engl f Med 1982;306:557-63.

2 Jamieson SW, Baldwin J, Reitz BA, et al. Combined heart and lung transplantation. Lance 1983;i:1130-2.

3 BurkeCM, Theodore J, Baldwin JC, et al. Twenty-eight cases of human heart-lung transplantation. Lancet 1986; i:517-9.

4 Reitz BA. Heart-lung transplantation: a review. Heart Transplantation 1982;1:291-7.

5 Jamieson SW, Stinson EB, Oger PE, Baldwin JC, Shumway NE. Operative techniques for heart lung transplantation. 7 Thorac Cardiovasc Surg 1984;87:930-5.

6 Meade F, Saunders MJ, Hyett F, Reynolds JA, Pearl N, Cotes JE. Automatic measurement of lung function. Lancet 1965;ii:573-5.

7 DuBois AB, Botelho SY, Bedell GN, Marshall R, Comroe JH. A rapid plethysmographic method for measuring thoracic gas volume. $\mathcal{F}$ Clin Invest 1956;35:322-6.

8 Burke CM, Theodore J, Dawkings KD, et al. Post-transplant obliterative bronchiolitis and other late lung sequelae in human heart-lung transplantation. Chest 1984;86:824-9.

9 Veith FJ. Lung transplantation in perspective. $N$ Engl f Med 1986;314:1186-7.

10 Hakim M, Wreghitt TG, English TAH, Stovin PGI, Cory-Pearce R, Wallwork J. Significance of donor transmitted disease in cardiac transplantation. Heart Transplantation 1985;4:302-6.

11 Jones DK, Hakim M, Wallwork J, Higenbottam TW. A serious interaction between cyclosporine A and sulphadimidine. Br Med f 1986;292:728-9.

12 Camner P, Strandberg K, Philipson K. Increased mucociliary transport by adrenergic stimulation. Arch Environ Health 1976;31:79-82.
13 Camner P, Strandberg K, Philipson K. Increased transport by cholinergic stimulation. Arch Environ Health 1974;29:220-4.

14 Theodore J, Jamieson SW, Burke CM, et al. Physiologic aspects of human heart-lung transplantation: pulmonary function status of the post-transplanted lung. Chest 1984;86: 349-57.

15 Locke TJ, Griffiths TL, Sutton A, Gibson GJ. Rib cage expansion after median sternotomy Thorax 1987;42:227-8.

16 Braun SR, Birnbuam ML, Chopra PS. Pre- and post-operative pulmonary function abnormalities in coronary artery revascularization surgery. Chest 1978;73:316-20.

17 Dark JH, Patterson FA, Al-Jalahauri AN, Hsu H, Egon T, Cooper JD. Experimental en-bloc double-lung transplantation. Ann Thorac Surg 1986;42:394-8.

18 Caves PK, Stinson EB, Billingham M, Rider AK, Shumway NE. Diagnosis of human cardiac allograft rejection by serial cardiac biopsy. I Thorac Cardiovasc Surg 1973;66:461-4.

19 McGregor CGA, Baldwin JC, Jamieson SW, Billingham ME, Yousen SA. Isolated pulmonary rejection after combined heart and lung transplantation. $\mathcal{F}$ Thorac Cardiovasc Surg 1985;90: rejection

20 Toronto Lung Transplant Group. Unilateral lung transplantation for pulmonary fibrosis. $N$ Engl f Med 1986;314:1140-5.

21 Veith FJ, Montefusco C, Kanholz SL, Mollenkopf FP. Lung transplantation. Heart Transplantation 1983;2:155-64.

22 Nelens JMB, Rebuck AS, Cooper JD, Goldberg M, Halloran PF, Vellend H. Human lung transplantation. Chest $1980 ; 78: 569-73$.

23 Stevens PM, Johnson PC, Bell RL, Beal AC, Jenkins DE. Regional ventilation and perfusion after lung transplantation in patients with emphysema. $N$ Engl f Med 1970;282:245-9.

24 Laurell CB, Eriksson S. The electrophoretic alpha-1-globulin pattern of serum in alpha-1antitrypsin deficiency. Scand $\mathcal{f}$ Clin Lab Invest 1962;15:132-40.

25 George PM, Vissers MCM, Travis J, Winterbourn CC, Carrell RW. A genetically engineered mutant of alpha-1-antitrypsin protects connective tissue from neutrophil damage and may be mutant of alpha-1-antitrypsin protects connective
useful in lung disease. Lancet 1984;ii: 1426-8.

26 Wood RE, Boat TT, Doershuk CF. State of the art; cystic fibrosis. Am Rev Respir Dis 1976;113:833-78.

27 Batten JC. Cystic fibrosis: coming of age. London: Pitman, 1983:367-83.

28 Penketh ARL, Knight RK, Hodson ME, Batten JC. Management of pneumothorax in adults with cystic fibrosis. Thorax 1982;37:850-3.

29 McCarthy M, Rourk MH, Spock A. Bacteraemia in patients with cystic fibrosis. Clin Paediatr 1980;19:746-8.

30 Nelson CA, Caccerame ML, Shwartz RA. Aspergillus and atopy in cystic fibrosis. Am Rev Respir Dis 1979;120:863-5.

31 Myers BD, Ross J, Newton L, Luetocher J, Perbroth M. Cyclosporin-associated chronic nephropathy. N Engl J Med 1984;311:699-705.

(Accepted 15 April 1987)

\title{
Epidemiological assessment of the health and nutrition of Ethiopian refugees in emergency camps in Sudan, 1985
}

\author{
PAUL SHEARS, ANGELA M BERRY, ROSANNE MURPHY, MICHAEL AZIZ NABIL
}

\begin{abstract}
The findings from epidemiological data that were collected from emergency camps for Ethiopian refugees during a mass influx of refugees into Eastern Sudan in 1985 are presented. An overall mortality of 8.9 per 10000 a day was recorded during February
\end{abstract}

Oxfam Health Unit, Oxford

PAUL SHEARS, $M B$, health adviser

United Nations High Commission for Refugees, CH-1211 Geneva ANGELA M BERRY, MSC, nutrition adviser

International Rescue Committee, Gedaref, Sudan

ROSANNE MURPHY, RN, MSC, public health programme coordinator

Commission of Refugees, Khartoum, Sudan

MICHAEL AZIZ NABIL, MD, health coordinator

Correspondence to: Dr P Shears, University Department of Medical Microbiology, Royal Liverpool Hospital, PO Box 147, Liverpool L69 3BX.
1985, and in children under 5 years of age the rate was 22 per 10000 a day. The estimated prevalence of malnutrition (calculated as less than $80 \%$ of the reference weight for height) ranged from $32 \%$ to $52 \%$ among children of preschool age. The principal causes of morbidity and mortality were measles, diarrhoea and dysentery, respiratory infections, and malaria.

The findings suggest that malnutrition and disease increased in these refugees after they arrived in the camps. Epidemiological assessment is essential to help to maintain the health and nutrition of refugees in emergency camps.

\section{Introduction}

Refugee emergencies are characterised by rapid mass migration and subsequent establishment of relief camps that are often large and unplanned. Because of the suddenness of such occurrences there may be insufficient water, food, and shelter in these camps, causing malnutrition and disease in the affected populations. ${ }^{1}$ The earliest medical response is often prompted by emotive media reports and not by epidemiological assessment, resulting in an overemphasis on 
curing people and subsequent high morbidity and mortality from preventable conditions.

The value of using epidemiological methods to improve health and nutrition in refugee emergencies has been shown in Bangladesh, ${ }^{2}$ Mauritania, ${ }^{3}$ and Thailand. ${ }^{4}$ We present the findings of epidemiological studies from refugee camps in eastern Sudan.

\section{Background}

The Ethiopian refugees who reside in Sudan comprise one of the largest refugee populations in Africa. Before the major influx of 1984-5 smaller movements of refugees had occurred after armed struggles between the liberation fronts and the government, but malnutrition and outbreaks of disease were not common in these smaller migrations. ${ }^{5}$ In $1984-5$ roughly 300000 refugees migrated over a six month period, and both famine and armed struggle were contributing factors. ${ }^{7}$ Despite international relief efforts there was considerable morbidity and mortality.

At the peak of the influx in January 1985 some 3000 refugees were crossing the Sudanese border every day, and they were accommodated in two large reception centres in Sudan, Wad Kowli and Wad Sherife (figure). Wad

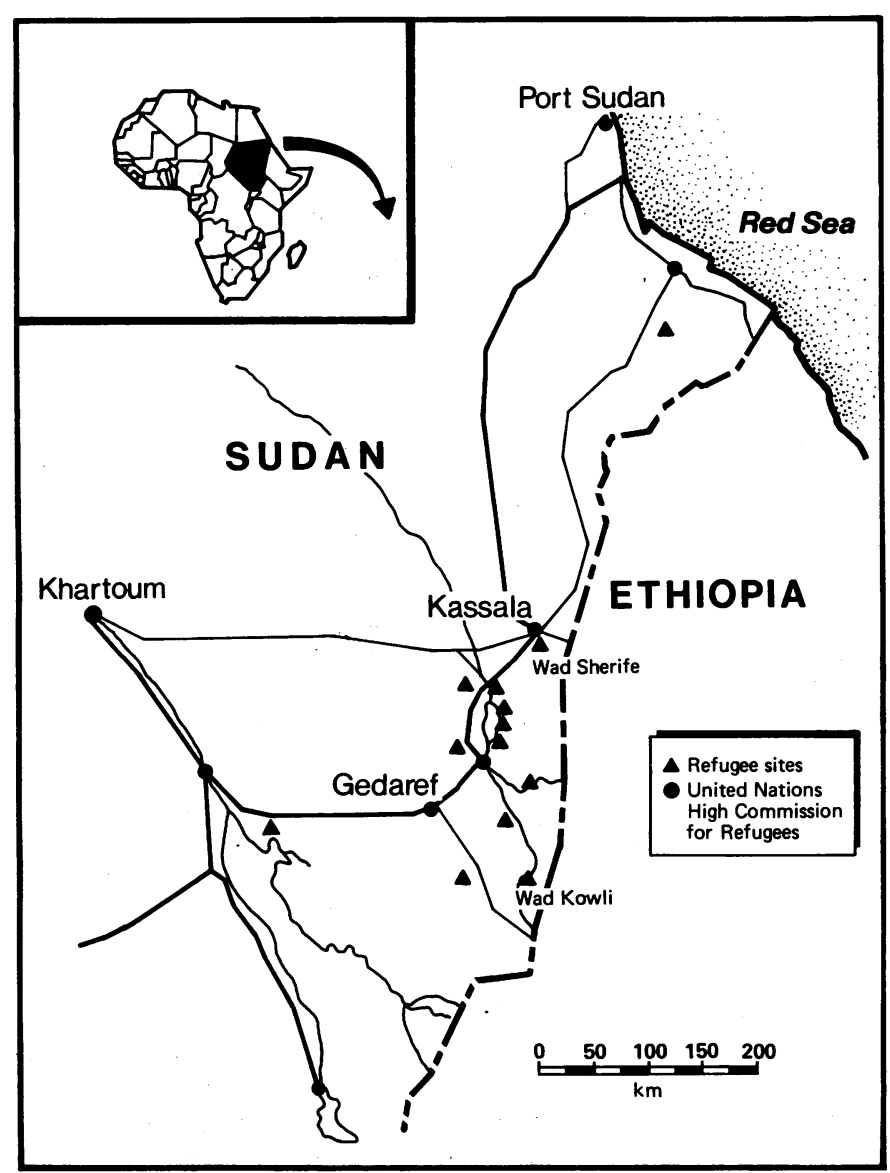

Map showing location of Wad Kowli and Wad Sherife camps in Sudan.

Kowli camp had an estimated population of 85000 Tigrayans by February 1985 and was situated between the border and the Sudanese town of Gedaref. Wad Sherife camp had nearly 65000 Eritrean refugees by February 1985 , and more than 100000 three months later, and was located near the town of Kassala. In addition to Wad Kowli and Wad Sherife, eight other relief camps were established in the first six months of 1985 . These included Fau, Wad El Hilieu, Hilat Hakuma, and Shagarab camps (not shown), the last two containing refugees who were relocated from Wad Kowli camp and Wad Sherife camps respectively.

The most complete data on mortality and morbidity were collected from Wad Kowli camp, and most of the information in this paper is from this population during the acute stages of the emergency. Data on nutrition were systematically collected from most reception centres throughout 1985 .

\section{Methods}

A survey of a random sample of households in Wad Kowli camp was carried out in February 1985 to assess the age and sex distribution of the population; 616 people lived in these households. Mortality data were gathered through a system of "grave watching." Two shifts of local staff covered a 24 hour period and control of burial sites was initiated. After discussion with relatives staff would classify deaths into measles, malaria, diarrhoea-dysentery, or chest infections. By February 1985 this system was well established in Wad Kowli and ensured that most deaths were registered. Case fatality rates were calculated from data combining morbidity assessment at clinics and mortality registration from grave watching. Additional data on mortality were gathered from a feeding centre for severely malnourished children in Fau 1 camp.

The nutritional state of preschool children was assessed in camps through random sample cluster surveys conducted by mobile teams between January and September 1985. There were 720 children from Wad Kowli and 480 children from Wad Sherife. Children who were under $110 \mathrm{~cm}$ in height were included (approximately equivalent to 5 years of age), and their weight, height, and mid-upper arm circumference were measured. Weight for height $(\mathrm{wt} / \mathrm{ht}$ ) values were determined using the Centers for Disease Control/ World Health Organisation reference standards ${ }^{8}$ and classification was based on agreed World Health Organisation standards': greater or equal to $80 \% \mathrm{wt} / \mathrm{ht}$ adequately nourished; $70-79 \% \mathrm{wt} / \mathrm{ht}$ moderately malnourished; and less than $70 \% \mathrm{wt} / \mathrm{ht}$ severely malnourished. The presence of oedema was classified in the severely malnourished category. Information on attendance at feeding centres was collected on each child in the surveys. In this paper the term "malnutrition" refers to children of less than $80 \%$ of the reference standard for weight for height.

Data on morbidity from Wad Kowli camp were collected in February 1985 from histories and physical examinations recorded in clinics and from initial studies using laboratory investigations of blood smears for malarial parasites. The clinical histories did not always allow for a distinction to be made between diarrhoea and dysentery so they were combined. In addition, data on the point prevalence of diarrhoea (more than four loose, watery stools on the previous day) were collected on each child included in the nutritional survey.

\section{Results}

Table I gives the distribution by age and sex of the population in Wad Kowli camp in February 1985. Altogether 616 people were covered by the survey: 305 (49\%) were children aged under 15 years. Females were underrepresented in both the under 5 age group and in the over 45 age group.

\section{MORTALITY}

During February in Wad Kowli camp 2140 deaths were registered by grave watchers. Age specific mortality (deaths per 10000 a day) from 25 January to 4 February for children under 5 years, children 5-14 years, and adults 15 years or older was $22,8.4$, and 2.9 respectively. Disease specific mortality (deaths per 10000 a day) for combined age groups was 4.4 for measles, 0.4 for malaria, $2 \cdot 1$ for diarrhoea-dysentery, and 0.4 for chest infections. In the under 5 age group the estimated measles mortality alone was 11 per 10000 a day.

Case fatality rates were as follows: measles (the worst outcome) 3:1 (2639 cases, 855 deaths); diarrhoea-dysentery 19:1 ( 8673 cases, 447 deaths); chest infections 39:1 (4184 cases, 104 deaths), which may have included some children with pneumonia following measles; and malaria 68:1 (7102 cases, 104 deaths).

As expected, highest mortality occurred in children in the severely malnourished category. In the survey of the therapeutic feeding centre in Fau 1 camp 72 out of 420 children died in a 15 day period in February, a mortality of 114 per 10000 a day.

\section{NUTRITIONAL STATE}

Table II gives the overall prevalence of malnutrition (less than $80 \%$ weight for height) from cross sectional surveys and screening of child populations from Wad Kowli and Wad Sherife. In January and February 1985 the overall prevalence of malnutrition in Wad Kowli camp was $32 \%$. Of the 230 malnourished children, $65(9 \%)$ were severely malnourished. In Wad Sherife the prevalence of malnutrition was $52 \%$, and of the 249 malnourished children, $96(20 \%)$ were severely malnourished.

Screening of 830 children under 5 who were moved from Wad Kowli to 
Hilat Hakuma camp five weeks after the original sample survey was carried out showed deterioration of nutritional state after arrival in camps. The overall prevalence of malnutrition increased from $32 \%$ ( 265 children) to $50 \%$ (415 children) during this period. Of the older children (5-14 years) included in this screening, $330(16 \%)$ were below $80 \%$ weight for height of the reference standard. The follow up random sample surveys conducted in June and September 1985 showed an apparent decline in the prevalence of malnutrition from $50 \%$ (415 of 830 children) to $15 \%$ ( 33 of 220 children) in the Wad Kowli population and from $52 \%$ ( 249 of 480 children) to $20 \%$ ( 46 of 232 children) in Wad Sherife.
10000 a day in non-drought years, ${ }^{3}$ whereas we found the overall mortality to be 8.9 per 10000 a day in Wad Kowli in February 1985. The mortality of 115 per 10000 a day among severely malnourished children in Fau camp emphasises the severity of this disaster, and it is notable that mortality continued to be high after the refugees arrived in the camps. Mortality has sometimes declined rapidly in refugees after a short period in relief camps: in Kampuchean refugee camps in Thailand there was a reduction in mortality from $9 \cdot 1$ per 10000 a day on arrival to 0.7 per 10000 a day one month

TABLE I-Age and sex distribution of population in sample survey $(n=616)$ in Wad Kowli camp, February 1985

\begin{tabular}{lcccc}
\hline & & \multicolumn{3}{c}{ Age (years) } \\
\cline { 3 - 5 } & $<5$ & $5-14$ & $15-45$ & $>45$ \\
\hline Male & 52 & 114 & 105 & 44 \\
Female & 38 & 101 & 133 & 29 \\
Total (\%) & $90(15)$ & $215(35)$ & $238(39)$ & $73(11)$ \\
\hline Total based on mean population of 85000 & 12750 & 29750 & 33150 & 9350 \\
\hline
\end{tabular}

TABLE II-Proportion of children $<110 \mathrm{~cm}$ in height with malnutrition

\begin{tabular}{|c|c|c|c|c|c|}
\hline Camp & Jan-Feb & March & April-May & June & Sept \\
\hline $\begin{array}{l}\text { Wad Kowli: } \\
\text { Sample size } \\
\text { No (\%) malnourished }{ }^{\star}\end{array}$ & $\begin{array}{l}720 \\
230(32)\end{array}$ & $\begin{array}{l}830 \\
415(50)\end{array}$ & $\begin{array}{l}2941 \\
1323(45)\end{array}$ & & $\begin{array}{l}220 \\
33(15)\end{array}$ \\
\hline $\begin{array}{l}\text { Wad Sherife: } \\
\text { Sample size } \\
\text { No (\%) malnourished }\end{array}$ & $\begin{array}{l}480 \\
249(52)\end{array}$ & & $\begin{array}{l}2616 \\
1072(41)\end{array}$ & $\begin{array}{l}232 \\
46(20)\end{array}$ & $\begin{array}{l}232 \\
46(20)\end{array}$ \\
\hline
\end{tabular}

*Less than $80 \%$ of the reference standard for weight for height.

Information collected in February on attendance at supplementary feeding centres showed that $65 \%$ ( 3536 of 5440 children) and $37 \%$ ( 1757 of 4750 children) of malnourished children were receiving supplementary food in Wad Kowli and Wad Sherife respectively. By September 1985 attendance had increased to $85 \%$ in Wad Kowli and $68 \%$ in Wad Sherife.

\section{MORBIDITY}

Information on morbidity was collected in outpatien clinics for adults and for under $5 \mathrm{~s}$ in Wad Kowli in February 1985. Table III gives morbidity data and disease attack rates according to age groups: $95 \%$ of clinic attendances were for new cases. The patterns in all age groups were similar for diarrhoeadysentery and malaria, with measles occurring in up to a fifth of children aged under 5 and 5-14. Non-specific aches and pains were also reported for adults.

\section{Discussion}

The disease and malnutrition problems that refugees face during mass exoduses have rarely been studied epidemiologically at the time of the crisis. We believe that the findings from this study question many of the assumptions on which current health programmes for refugees are based and suggest more appropriate interventions.

Although numbers of deaths are quoted often in the media and in publicity from relief agencies, accurate mortality data have rarely been collected in refugee camps. The grave watching system, combined with a simple classification by age and cause of death, enabled age and disease specific mortality to be determined with reasonable accuracy. Mortality is not a good indicator of the severity of such disasters because there are few comparative data from other disasters or for non-disaster years in most of the areas that are prone to droughts and influxes of refugees. Data collected by the Centers for Disease Control in the Sahel region suggest a mortality of 0.5 per later. ${ }^{4}$ In Sudan mortality continued in the range 6-10 per 10000 a day for the first six months of the disaster (Commission of Refugees Health Unit, eastern Sudan, 1985, internal report). Persistently high mortality may be due to a continuing influx of new arrivals, high malnutrition rates, and a high prevalence of diseases such as measles and gastroenteritis, all of which featured in the Sudan camps.

TABLE III-Disease specific morbidity and attack rates by age group in Wad Kowli Camp, February 1985 (from clinic visits)

\begin{tabular}{|c|c|c|c|c|c|c|}
\hline \multirow[b]{4}{*}{ Diagnosis } & \multicolumn{6}{|c|}{ Age (years) } \\
\hline & \multicolumn{2}{|l|}{$<5$} & \multicolumn{2}{|l|}{$5-14$} & \multicolumn{2}{|c|}{$>14$} \\
\hline & Clinic visits & Attack & Clinic visits & Attack & Clinic visits & Attack \\
\hline & No (\%) & 1000 & No (\%) & 1000 & No (\%) & 1000 \\
\hline $\begin{array}{l}\text { Malaria } \\
\text { Measles } \\
\text { Diarrhoea-dysentery } \\
\text { Chest infections } \\
\text { Aches and pains } \\
\text { Others }\end{array}$ & $\begin{array}{r}1424(23) \\
1232(20) \\
1733(28) \\
805(13) \\
\\
925(15)\end{array}$ & $\begin{array}{r}112 \\
97 \\
130 \\
63\end{array}$ & $\begin{array}{l}2099(25) \\
1407(16) \\
2331(27) \\
1404(16) \\
1289(15)\end{array}$ & $\begin{array}{l}70 \\
47 \\
78 \\
47\end{array}$ & $\begin{array}{l}3579(19) \\
120(<1) \\
4609(24) \\
1925(10) \\
2197(12) \\
6310(33)\end{array}$ & $\begin{array}{c}84 \\
2 \cdot 0 \\
108 \\
45\end{array}$ \\
\hline Total No of attendances & s 6119 & & 8530 & & 18740 & \\
\hline
\end{tabular}

Data on mortality have two important uses in managing the health of refugees. They may be used as indicators to determine whether additional relief measures are required. So long as mortality is considerably greater than that in normal years it may be considered that morbidity and mortality are exceeding health inputs. When mortality has declined continuing inputs will be required to maintain stability, but additional relief agencies are unlikely to be required. Secondly, disease and age specific mortality, combined with data on disease and age specific attack rates and case fatality ratios, enable the health programmes in camps to be directed to the principal causes of morbidity and mortality (table IV).

Measles was the main cause of mortality in Wad Kowli, being responsible for 855 recorded deaths in February 1985, mostly among children under 10 years of age. The very high case fatality rate of 3:1 may be an overestimate, as it is probable that not all cases of measles were reported to the clinics. Allowing for this, measles still had a devastating impact. Few data were available on the prevalence of measles among children on arrival or on the time of infection after arrival. Although measles may have been present and caused some morbidity and mortality before arrival in the 
camps, we believe that most of the morbidity and mortality occurred after arrival. The case fatality rate was at least $300 \%$ greater than that recorded by the Centers for Disease Control study in Mauritania ${ }^{3}$ and was associated with high rates of malnutrition and gastroenteritis. Although some reduction in measles morbidity has occurred using refugee health workers, ${ }^{10}$ priority must be given to immunisation to reduce attack rates. Measles immunisation was started in Wad Kowli during the second week of January, initially for children 6 months to 5 years of age, and then extended to children up to 10 . Cases of measles presenting to clinics declined from 898 in the week 1-7 February to 81 in the week 22-28 February. In future mass exoduses of refugees in Africa measles immunisation of newly arrived refugees aged 6 months to 10 years must be a priority-there is little excuse for relief teams to arrive without a measles vaccination system.

TABLE IV-Use of epidemiological data to plan health care

\begin{tabular}{|c|c|c|c|c|}
\hline Disease & $\begin{array}{c}\text { Attack rate } \\
\text { (cases/1000 } \\
\text { children under } \\
5 \text { years) }\end{array}$ & $\begin{array}{l}\text { Case fatality } \\
\text { ratio }\end{array}$ & $\begin{array}{l}\text { Decrease attack } \\
\text { rate }\end{array}$ & Decrease morbidity \\
\hline Diarrhoea & 130 & 19:1 & $\begin{array}{l}\text { Improve water } \\
\text { sanitation }\end{array}$ & $\begin{array}{l}\text { Sector level oral } \\
\text { rehydration } \\
\text { programme }\end{array}$ \\
\hline $\begin{array}{l}\text { Measles } \\
\text { Malaria }\end{array}$ & $\begin{array}{r}97 \\
112\end{array}$ & $\begin{array}{r}3: 1 \\
68: 1\end{array}$ & $\begin{array}{l}\text { Immunisation } \\
\text { Vector control } \\
\text { ? prophylaxis }\end{array}$ & $\begin{array}{l}\text { Supportive care } \\
\text { Early diagnosis and } \\
\text { treatment }\end{array}$ \\
\hline Chest infections & 63 & $39: 1$ & Improve shelter & $\begin{array}{l}\text { Early diagnosis and } \\
\text { treatment }\end{array}$ \\
\hline
\end{tabular}

The disease specific attack rate for diarrhoeal diseases in children under 5 of 130 per 1000 a month is probably an underestimate as not all cases presented to clinics. During a population survey of nutritional state diarrhoea in the previous 48 hours was reported in $252(35 \%)$ of 720 children. Morbidity and mortality due to diarrhoeal diseases may be reduced by two approaches. Attack rates may be reduced by improved water supply and sanitation. In practice such improvements may be very difficult to achieve in the early stages of a refugee crisis. While some attempts were made at constructing latrines surface disposal was usually the rule, particularly by children with gastroenteritis. Providing a protected water supply is easier than improving sanitation and should reduce point source water borne diseases. The transmission of diarrhoeal disease, however, probably occurs in and around the refugee huts and is unlikely to be reduced by point source provision of clean water. Data from non-refugee areas show little reduction in diarrhoeal diseases by improvements in water supply alone. ${ }^{11}$ The second approach, particularly in reducing infantile gastroenteritis, is not to reduce attack rates but to provide effective and early oral rehydration treatment. In Wad Kowli community health workers provided oral rehydration in each sector of the camp. The relatively low case fatality rate due to diarrhoeal diseases (probably considerably lower than the calculated rate of 19:1 owing to under-reporting of cases) reflects the effectiveness of this programme.

Malaria was an important cause of morbidity in all age groups. In a sample survey 132 of $336(39 \%)$ patients who presented with fever and chills had blood films that were positive for malaria, and of these, 124 (94\%) showed Plasmodium falciparum. The relatively low case fatality rate of malaria (68:1) may be accounted for $(i)$ by a relatively immune population reducing the severity of malaria and (ii) by giving chloroquine to patients who were suspected of having malaria. Strategies of reducing the morbidity and mortality from malaria may be directed to both reducing disease attack rates, by vector control or prophylaxis, and reducing morbidity in patients through early diagnosis and treatment. Effective vector control was restricted in the camps because of the many breeding sites in the river bed pools and because insecticides could not be applied to stick and grass huts. Although chemoprophylaxis may be appropriate for certain vulnerable groups, problems with compliance and possible effects on immunity and resistance make its value limited for whole populations in camps. Thus early diagnosis and treatment, as practised in Wad Kowli, is probably the best strategy for large populations of refugees.

Nutritional state can be measured quantitatively and therefore is a useful comparative indicator of the severity of the disaster. The prevalence of malnutrition recorded in Wad Kowli and Wad Sherife camps in February 1985 (30\% and $52 \%$ respectively) may be compared with $17 \%$ in the 1974 Sahel drought ${ }^{3}$ and $25 \%$ in Ugandan refugees in Sudan in 1982. ${ }^{12}$ The deterioration in the nutrition of refugees in Wad Kowli camp from February to May 1985 is of considerable concern. This may be partly explained by new children arriving in the camp malnourished. Follow up, however, on a group of children who moved from Wad Kowli to Hilat Hakuma camp showed an increase in malnutrition from $32 \%$ to $50 \%$, and there were no arrivals from outside. There are several explanations for the increase in malnutrition. Shortage of general rations in the camp cannot be excluded. The very high influx of refugees during January of over 1000 a day was greater than most predictions. This resulted in less than the planned daily per caput relief ration of $7.733 \mathrm{MJ}$ being available. In addition, grinding facilities were not available so that much of the ration was consumed as roasted whole grain, which was noted to be poorly used by most children. The high prevalence of measles and gastroenteritis must also have contributed to the decline in nutrition after arrival in the camp.

The apparent decline in the prevalence of malnutrition that was recorded from May to September in Wad Kowli camp and from January to June in Wad Sherife camp must be interpreted cautiously as mortality among malnourished children was not included. If there had been considerable mortality among malnourished children they would be under-represented in follow up surveys, indicating wrongly that the prevalence of malnutrition had decreased.

Malnutrition was not included as a separate cause of mortality in the study. Though quantitative data are not available, in most observed deaths of malnourished children (in therapeutic feeding programmes) gastroenteritis, chest infections, or measles were associated with the cause of death.

Although this population was physically vulnerable owing to previous famine and migration, an increase in the frequency and severity of malnutrition and certain illnesses occurred after arrival in camps. Most communicable diseases acquired in the camps were related to potentially preventable risk factors (table $\mathrm{V}$ ). The findings

TABLE v-Communicable disease risk factors in refugee camps

\begin{tabular}{|c|c|c|c|}
\hline \multirow[b]{2}{*}{ Water and sanitation } & \multicolumn{2}{|c|}{ Crowding } & \multirow[b]{2}{*}{ Poor shelter } \\
\hline & Direct & Vector related & \\
\hline $\begin{array}{l}\text { Gastroenteritis } \\
\text { Dysentery } \\
\text { Cholera } \\
\text { Polio } \\
\text { Typhoid } \\
\text { Hepatitis } \\
\text { Bilharzia }\end{array}$ & $\begin{array}{l}\text { Measles`} \\
\text { Meningitis } \\
\text { Tuberculosis } \\
\text { Diphtheria } \\
\text { Whooping cough } \\
\text { Scabies } \\
\text { Trachoma }\end{array}$ & $\begin{array}{l}\text { Typhus } \\
\text { Relapsing fever } \\
\text { Malaria }\end{array}$ & Pneumonia ${ }^{\star}$ \\
\hline
\end{tabular}

The four main causes of morbidity and mortality associated with malnutrition in most camps.

of our study suggest that epidemics and high mortality are not inevitable consequences in refugee camps but result from predictable diseases for which attack rates and fatality rates may be reduced by planned prevention and treatment. In future mass movements of refugees relief agency inputs should be based on epidemiological data, and surveillance systems should be set up to monitor the effectiveness of health and nutrition programmes.

We thank Save the Children Fund (UK), the International Rescue Committee, Médecins Sans Frontières (France), and the League of Red Cross and Red Crescent Societies, Geneva, for contributing data; Dr Richard Steketee of Centers for Disease Control, Atlanta, for his efforts in establishing data collection systems in Wad Kowli and for technical and editorial advice on this paper; Drs Michel Gabaudan (UNHCR), Richard Nesbit (UNHCR), and Vincent David and Serge Manoncourt (MSF) for contributions and support; and those who helped in the nutrition survey. 


\section{References}

1 Simmonds SP, Vaughan JP, Gunn SW, eds. Refugee community health care. Oxford: Oxford University Press, 1983:357.

2 Seaman JA. Relief work in a refugee camp for Bangladesh refugees in India. Lancet 1972;ï:866-70. 3 Greene MH. Impact of Sahelian drought in Mauritania, West Africa. Lancet 1974;i:1093-6.

4 Glass RI, Cates W, Neiburg P, et al. Rapid assessment of health status and preventive medicine needs of newly arrived Kampuchean refugees, Sa-Keo, Thailand. Lancet 1980;i:868-72.

5 Steketee RW, Mulholland K. Primary care medicine in refugee relief program of eastern Sudan. Disasters 1982;6:176-82.

6 Johnson T. Eritrea refugees in Sudan. Disasters 1979;3:417-21.

7 United Nations High Commission for Refugees. Public information report. Khartoum: UNHCR, 1985.
8 Graiter PL. A manual for the basic assessment of nutritional status in potential crisis situations. Atlanta GA: Centers for Disease Control, 1981.

9 Ville de Goyet C, Seaman J, Geljer U. The management of nutritional emergencies in large populations. Geneva: World Health Organisation, 1978:98.

10 Drew $D$, Bauhaun $M$. Effective deployment of refugee health workers in epidemic measles. Trop Doct 1982;12:132-3.

11 Levine RJ, D'Souza S. Failure of sanitary wells to reduce diarrhoeal disease incidence. Lancet 1976;ii:86.

12 Shears P. Nutrition studies of Ugandan refugees in Sudan and Rwanda. Trop Geogr Med 1985;37:359-61.

(Accepted 14 April 1987)

\title{
Lesson of the Week
}

\section{"Patients with terminal cancer" who have neither terminal illness nor cancer}

\author{
W D REES, S B DOVER, T S LOW-BEER
}

A person is terminally ill when after correct diagnosis and appropriate treatment the disease remains progressive, death is inevitable in the short term, and the practical need is for care not cure. We report on four patients wrongly referred for care for terminal cancer. Although they represent only a small proportion of referrals for hospice care (four of 1635 admissions), they were not terminally ill and the misdiagnoses were therefore important.

\section{Case 1}

A 70 year old man was admitted to hospital with a painful right hip and a pleural effusion. A pleural biopsy specimen was scanty, but two histopathologists thought that it showed small round cell malignancy, possibly lymphoma but more probably anaplastic carcinoma. His general condition was poor and he was given palliative radiotherapy to the hip, which improved the pain. Two months later he was admitted for hospice care.

Five months later he was referred back to hospital for reassessment. Although plasma electrophoresis showed an IgA paraprotein, the results of bone marrow aspirations were normal and no trace of malignancy could be detected. A total hip replacement was performed, and histological examination showed osteoarthrosis but no malignancy. A third histopathologist, asked to examine the original pleural biopsy specimen, also diagnosed small round cell malignancy. Three years later the patient was robust, cheerful, and living alone.

\section{Case 2}

A 75 year old woman had a haematemesis while being treated in hospital for heart failure. Endoscopy showed a gastric ulcer, which was considered by the endoscopist to be benign. The histologist, however, reported the

\section{St Mary's Hospice, Birmingham B29 7DA \\ W D REES, MD, FRCGP, medical director \\ $S$ B DOVER, MB, medical registrar}

Selly Oak Hospital, Birmingham B29 6JD

T S LOW-BEER, MA, FRCP, consultant physician

Correspondence to: Dr Rees.

\section{Some patients are referred for terminal care as a result of misdiagnosis}

endoscopic biopsy specimens as showing a poorly differentiated infiltrating, mucin secreting adenocarcinoma. This diagnosis was accepted. Bedbound and too ill for surgery, the patient was transferred to a hospice with an estimated life expectancy of three weeks. Her condition improved and she became cheerful and ambulant and gained weight. Five months later she was reviewed by the gastroenterologist, who considered the diagnosis to be still probably correct.

Three months later endoscopy showed an ulcer $5 \mathrm{~mm}$ in diameter on the lesser curve; the earlier biopsy specimens were reviewed and the report of poorly differentiated adenocarcinoma retracted. She was discharged home. Endoscopy three years later showed gastric scarring but no ulceration, and biopsy from a slightly irregular area and oesophageal brushings showed no evidence of cancer. Four years after admission to the hospice she was ambulant and cheerful, although she required treatment for cardiac failure.

\section{Case 3}

A 65 year old woman was referred from another hospital for hospice care four years after a cholecystoduodenostomy for pancreatic cancer. At operation the entire pancreas had been found to be affected by cancer, which was infiltrating the surrounding structures but had not metastasised to the liver or lymph nodes. The cancer was considered to be inoperable. A transduodenal needle biopsy of the pancreas showed no tumour, but the diagnosis was not revised in the light of this report.

Nine months later she had a coeliac plexus block for abdominal pain. Four years after the operation her multiple abdominal pains, which required regular oral and intramuscular opioids, led to referral to the hospice. One of us (WDR) saw her at home and thought she looked remarkably well for a woman with terminal pancreatic cancer. There was obvious stress within the family, and the patient, although ambulant, had refused to walk downstairs for three months. She knew that cancer of the pancreas had been diagnosed and that three years before her ovaries and right breast had been removed for breast cancer. She had not attended the outpatient clinic for three years.

In the hospice she was weaned off opioids in three weeks. Finding no evidence of breast or pancreatic cancer, her surgeon concluded that the 